\title{
ULOGA I ZNAČAJ DRŽAVNIH SLUŽBENIKA U OSTVARIVANJU PRAVA GRAĐANA NA LOKALNU SAMOUPRAVU U FEDERACIJI BOSNE I HERCEGOVINE
}

\author{
UDK: 352 (497. 6) \\ Primljeno: ožujak 2017. \\ Pregledni rad
}

\begin{abstract}
U radu se daje kratak pregled ustavnog uređenja Bosne i Hercegovine i Federacije Bosne i Hercegovine te položaja lokalne samouprave u vertikalnom ustroju vlasti. Pored toga, tretira se pitanje organizacije i nadležnosti jedinica lokalne samouprave. U radu se obrađuje pitanje prava na lokalnu samoupravu koju garantira Ustav Federacije Bosne i Hercegovine. Fokus istraživanja je usmjeren na službeničko pravo u Federaciji Bosne i Hercegovine, odnos političkih struktura prema službeničkoj profesionalnoj neovisnosti i ulogu i značaj koji državni službenici treba da imaju u postupcima ostvarivanja građanskih prava, odnosno prava na lokalnu samoupravu. Autor ukazuje na nužnost harmonizacije kantonalnog zakonodavstva iz oblasti službeničkog prava sa federalnim zakonodavstvom, te potrebu utemeljenosti službeničkog prava na načelima i dostignutim standardima u Europskoj uniji.
\end{abstract}

Ključne riječi: Federacija Bosne i Hercegovine, lokalna samouprava, državni službenik, dobra uprava

\section{UVOD}

Bosna i Hercegovina $(\mathrm{BiH})$ ima specifično ustavno uređenje. Čine je dva entiteta i Distrikt Brčko kojeg Ustav BiH konstituše kao jedinicu lokalne samouprave, kao kondominij entiteta. Federacija BiH se dalje dijeli na federalne jedinice - 10 kantona/županija. Kantoni/županije na općine. U Republici Srpskoj nema federalnih jedinica već samo općine.

Federacija $\mathrm{BiH}$ je jedan od dva entiteta $\mathrm{BiH}$. Sastoji se od 10 federalnih jedinica (kantona/županija) i 80 jedinica lokalne samouprave od kojih šest imaju status grada. Dva grada, Sarajevo i Mostar, uspostavljeni su Ustavom Federacije Bosne i Hercegovine 1994. godine, a ostala četiri, Grad Tuzla, Grad Široki Brijeg, Grad Zenica i Grad Bihać, tek nedavno, 2014. godine zakonima.

Općinsku/gradsku strukturu čine dva organa: općinsko/gradsko vijeće kao predstavnički organ i općinski načelnik, odnosno gradonačelnik u gradovima kao izvršni organ. 
Ustav BiH, osim u dijelu koji se odnosi na Distrikt Brčko, ne tretira pojam lokalne samouprave. Ustav Federacije $\mathrm{BiH}$ reguliše pitanje lokalne samouprave vrlo restriktivno. Tako u članu VI.1. Ustava Federacije BiH utvrđeno je da općina u vršenju svojih nadležnosti poduzima sve potrebne mjere u cilju zaštite prava i sloboda utvrđenih u članovima II.A.1. do 7. i u instrumentima navedenim u Aneksu, vodi računa o nacionalnoj strukturi stanovništva u općini. Također, u ovom članu VI.1.c) garantira se konstitutivnim narodima i pripadnicima ostalih proporcionalna zastupljenost u općinskim organima vlasti. Ta zastupljenost odražava popis stanovništva iz 1991. godine do potpune provedbe Aneksa 7. u skladu sa članom IX.11.a. Ustava Federacije BiH. U članu VI.2. utvrđeno je da se u općini ostvaruje lokalna samouprava, te da općina ima statut koji mora biti u skladu sa Ustavom, kantonalnim ustavom i kantonalnim zakonodavstvom.

Ustavom se, dalje, razrađuju nadležnosti i izbor općinskog vijeća i općinskog načelnika, te osnivanje i nadležnosti općinskih sudova. Tako se u članu VI.3. propisuje da općina ima općinsko vijeće i općinskog načelnika, da im, članovima općinskog vijeća i općinskom načelniku, mandat traje četiri godine, te da ih se bira demokratskim putem, na neposrednim i tajnim izborima na cijelom području općine na način kako je utvrđeno zakonom.

U članu VI.4. se utvrđuju nadležnosti općinskog vijeća da usvaja statut, općinski budžet, da donosi propise o oporezivanju, te da na druge načine osigurava potrebno finansiranje koje nije osigurala kantonalna ili federalna vlast. Također, općinsko vijeće donosi propise u izvršavanju općinskih nadležnosti. Dalje, u članu VI.5. se propisuje da općinsko vijeće stvara uvjete za izbor općinskog načelnika, te donosi svoj poslovnik koji mora biti u skladu sa federalnim i kantonalnim zakonodavstvom. Istim članom se utvrđuje javnost rada općinskog vijeća, odnosno javnost zasjedanja općinskog vijeća osim u izuzetnim okolnostima koje općinsko vijeće može predvidjeti u svom poslovniku, kao i da se vodi zapisnik o donesenim odlukama.

Ustav Federacije BiH, pored nadležnosti općinskog vijeća, utvrđuje i nadležnosti općinskog načelnika. Tako u članu VI.6. se utvrđuje da je općinski načelnik nadležan za imenovanje i smjenjivanje općinskih službenika, zatim za provođenje općinske politike, izvršavanje općinskih propisa i delegiranih ili prenesenih nadležnosti općini od kantonalnih ili federalnih vlasti. Dalje, utvrđuje se da je općinski načelnik nadležan za osiguranje saradnje općinskih službenika sa ombudsmenima, te da podnosi izvještaj općinskom vijeću i javnosti o provođenju općinske politike i svojih aktivnosti.

U poglavlju VI.A. Ustava Federacije BiH regulirane su gradske vlasti. Ovo poglavlje dodano je amandmanom XVI na Ustav Federacije BiH. Kasnije je i ovo poglavlje mijenjano amandmanom XXV, amandmanom LXXXVII i amandmanom C. Iza ovog poglavlja, amandmanom XXVI, dodano je još jedno poglavlje koje se odnosi na grad, a to je poglavlje VI.B. Organizacija Sarajevo. Nešto kasnije, Odlukom Visokog predstavnika u BiH Paddya Ashdowna proglašeni su amandmani XCV-CII. Ovim amandmanima, tačnije amandmanom CI dodan je novi član VI.C. Organizacija Mostara. 
U poglavlju VI.A. se određuje da se za područje dvije ili više općina, koje su urbano i teritorijalno povezane svakodnevnim potrebama građana formira grad kao jedinica lokalne uprave i samouprave, u skladu sa federalnim zakonom. Ustav propisuje i nadležnosti odnosno odgovornosti grada koje obuhvataju: finansije i poresku politiku, zajedničku infrastrukturu, urbanističko planiranje, javni promet te druge nadležnosti koje gradu povjeri kanton odnosno prenesu općine.

Grad, kako je utvrđeno Ustavom Federacije $\mathrm{BiH}$, ima statut, gradsko vijeće i gradonačelnika. Gradsko vijeće, kojeg čine vijećnici iz općina koje ulaze u sastav grada, usvaja statut grada, bira gradonačelnika, donosi budžet grada i propise u izvršavanju ovlaštenja. Gradonačelnik imenuje i smjenjuje gradske funkcionere, provodi gradsku politiku i izvršava gradske propise, osigurava saradnju gradskih funkcionera sa ombudsmenima te podnosi izvještaj gradskom vijeću i javnosti.

Zakon o principima lokalne samouprave u Federaciji Bosne i Hercegovine (u daljem tekstu: Zakon o principima) detaljnije reguliše pitanje lokalne samouprave. Kada je riječ o nadležnostima jedinica lokalne samouprave Zakon o principima općom klauzulom utvrđuje da se jedinice lokalne samouprave ,imaju pravo baviti svim pitanjima od lokalnog značaja koja nisu isključena iz njene nadležnosti niti dodijeljena u nadležnost neke druge vlasti na osnovu ustava i zakona". Pored toga Zakon o principima u članu 8. taksativno pobraja vlastite nadležnosti jedinica lokalne samouprave. Pored ostalog utvrđena je nadležnost za: osiguranje i zaštitu ljudskih prava i osnovnih sloboda; donošenje budžeta; utvrđivanje i provođenje politike uređenja prostora i zaštite čovjekove okoline; donošenje prostornih, urbanističkih i provedbenih planova, uključujući zoniranje; utvrđivanje i provođenje stambene politike i donošenje programa stambene i druge izgradnje; utvrđivanje politike korištenja i utvrđivanje visine naknada za korištenje javnih dobara; utvrđivanje i vođenje politike raspolaganja, korištenja i upravljanje građevinskim zemljištem; utvrđivanje politike upravljanja prirodnim resursima jedinice lokalne samouprave i raspodjele sredstava ostvarenih na osnovu njihovog korištenja; upravljanje, finansiranje i unapređenje djelatnosti i objekata lokalne komunalne infrastrukture; vodosnabdijevanje, odvođenje i preradu otpadnih voda; prikupljanje i odlaganje čvrstog otpada; održavanje javne čistoće; gradska groblja; lokalne puteve i mostove; uličnu rasvjetu; javna parkirališta; parkove; utvrđivanje politike predškolskog obrazovanja, unapređenje mreže ustanova, te upravljanje i finansiranje javnih ustanova predškolskog obrazovanja; osnivanje, upravljanje, finansiranje i unapređenje ustanova osnovnog obrazovanja; osnivanje, upravljanje, unapređenje i finansiranje ustanova i izgradnju objekata za zadovoljavanje potreba stanovništva u oblasti kulture i sporta; ocjenjivanje rada ustanova i kvaliteta usluga u djelatnosti zdravstva, socijalne zaštite, obrazovanja, kulture i sporta; analizu stanja javnog reda i mira, sigurnosti ljudi i imovine, te predlaganje mjera prema nadležnim organima za ova pitanja; organiziranje, provođenje i odgovornost za mjere zaštite i spasavanja ljudi i materijalnih dobara od elementarnih nepogoda i prirodnih katastrofa; uspostavljanje i vršenje inspekcijskog nadzora nad izvršavanjem propisa iz vlastitih nadležnosti jedinice lokalne samouprave; donošenje propisa o porezima, naknadama, doprinosima i taksama iz nadležnosti jedinice lokalne samouprave; 
raspisivanje referenduma za područje jedinice lokalne samouprave; poslove iz oblasti premjera i katastra zemljišta i evidenciju o nekretninama.

Iako su kao jedinice lokalne samouprave utvrđeni gradovi i općine, zakon ne utvrđuje različite nadležnosti za jedinice lokalne samouprave iz čega proizilazi da je u Federaciji BiH organiziran jedan tip lokalnih jedinica tj. monotipska struktura lokalne samouprave. Međutim, postoje izuzeci. Tako Ustav Kantona Sarajevo i Ustav Bosansko-podrinjskog kantona (Kantona Goražde) utvrđuju da općine mogu imati različite nadležnosti zavisno od globalne politike funkcioniranja i razvoja Kantona, te od ekonomskog, prostornog i drugog položaja pojedinih općina. Na ovaj način se ostavlja mogućnost politipskog ustroja općina na području ovih kantona.

Pored organa općine/grada (općinskog načelnika/gradonačelnika i općinskog/ gradskog vijeća), Zakon o organizaciji organa uprave u Federaciji BiH propisuje uvjete i način formiranja općinskih ili gradskih službi za upravu, definirajući ih kao organe uprave koji se osnivaju za „obavljanje upravnih i stručnih poslova iz samoupravnog djelokruga općine, odnosno grada“. Poslove osnovne djelatnosti organa uprave obavljaju državni službenici, a poslove dopunske i pomoćne djelatnosti obavljaju namještenici.

\section{PRAVO NA LOKALNU SAMOUPRAVU U FEDERACIJI BOSNE I HERCEGOVINE}

Pojam lokalna samouprava se često poistovjećuje sa pojmom lokalne zajednice. Međutim, pojam lokalna samouprava je širi od pojma lokalna zajednica i podrazumijeva: ,,... lokalnu zajednicu koja ima status samouprave. Lokalna zajednica je jedino nosilac (lokalne) samouprave, njen subjekt; a (lokalna) samouprava je pravnosistemska institucija, koja opredjeljuje položaj (status) lokalne zajednice." (Šmidovnik, J., 1999., str. 23.)

Šmidovnik (1999.) kao bitne konstitutivne elemente institucije lokalne samouprave ističe nekoliko elemenata samoupravnosti, $i$ to:

- teritorijalni: da su teritorijalno određene i međusobno razgraničene lokalne zajednice osnovane kao subjekti lokalne samouprave, naprimjer kao općine, pokrajine itd.;

- funkcionalni: da je ovim zajednicama priznato radno područje zadataka, koji izražavaju interese njihovih stanovnika;

- organizacioni: da ove zadatke obavljaju članovi zajednice vlastitom odgovornošću, i to bilo neposredno ili putem svojih organa koje su izabrali;

- materijalno-finansijski: da zajednica ima vlastita materijalna i finansijska sredstva za obavljanje svojih zadataka i

- pravni: da zajednica ima karakter pravnog lica.

Dakle, tek kada se lokalnoj zajednici pridodaju navedeni elementi, smatra Šmidovnik,postala bi lokalna samouprava. 
Zakon o principima u članu 2. definira lokalnu samoupravu kao „pravo i osposobljenost jedinica lokalne samouprave da, u granicama zakona, reguliraju i upravljaju određenim javnim poslovima na osnovu vlastite odgovornosti i u interesu lokalnog stanovništva“. Dakle, Zakon o principima je u potpunosti preuzeo formulaciju pojma lokalne samouprave iz Europske povelje o lokalnoj samoupravi - EPLS (European Charter of Local Self-Government).

Ustav Federacije BiH, u članu VI.2. utvrđuje, tek, da se u općini ostvaruje lokalna samouprava, bez daljnih garancija prava na lokalnu samoupravu, kao što je to učinjeno, primjerice, u susjednoj R. Hrvatskoj. Međutim, kada je riječ o pravu na lokalnu samoupravu, naročito o zaštiti prava na lokalnu samoupravu, ovu odredbu treba posmatrati u kontekstu člana VII.3. Ustava, kojim je utvrđeno da međunarodni ugovori i drugi sporazumi koji su na snazi u BiH i Federaciji BiH, kao i opća pravila međunarodnog prava jesu dio zakonodavstva Federacije BiH, te utvrđuje i primat međunarodnih ugovora i sporazuma nad zakonodavstvom Federacije $\mathrm{BiH}$. $\mathrm{BiH}$ je Europsku povelju o lokalnoj samoupravi ratificirala 1994. godine. Temeljem ovakve ustavne odredbe, Ustavni sud Federacije $\mathrm{BiH}$, rješavajući o zahtjevima jedinica lokalne samouprave za zaštitu prava na lokalnu samoupravu, u do sad gotovo svim slučajevima u kojima je utvrdio povredu prava na lokalnu samoupravu, je svoju odluku zasnivao na odredbama Europske povelje o lokalnoj samoupravi. Uglavnom se radilo o propuštanju obaveze viših razina vlasti da konsultiraju jedinice lokalne samouprave u postupcima donošenja propisa koji ih se direktno tiču. Ova obaveza konsultiranja utvrđena je u članu 56. Zakona o principima i u članu 4. tačka 6. Europske povelje o lokalnoj samoupravi.

Nadležnost Ustavnog suda Federacije BiH utvrđena je članom IV.C.10. Ustava Federacije BiH. Ovaj član je dopunjen Amandmanom XCVI kojim se utvrđuje nadležnost Ustavnog suda da odlučuje o zahtjevu za zaštitu prava na lokalnu samoupravu, kojeg mogu podnijeti općine i gradovi i udruženja općina i gradova Federacije BiH. Do donošenja ovog Amandmana, Ustavni sud je u skladu sa članom IV.C.10.(1) imao, kada su općine i gradovi u pitanju, nadležnost rješavanja sporova između grada i njegovog kantona ili federalne vlasti, između općine i grada te između općina i njihovih kantona ili federalne vlasti.

Dakle, državni službenici nemaju stranačku legitimaciju za podnošenje zahtjeva za zaštitu prava na lokalnu samoupravu. No ipak, značaj državnih službenika, kada je riječ o pravu na lokalnu samoupravu, leži u činjenici da su državni službenici uključeni direktno ili indirektno u obavljanje svih poslova iz nadležnosti jedinica lokalne samouprave. Sve odluke koje donose općinska vijeća pripremaju državni službenici. Iako, općinski vijećnici mogu predlagati općinskom vijeću sve opće akte za čije donošenje je nadležno općinsko vijeće, u praksi to vijećnici gotovo nikada ne čine. Također, sve akte koje donosi općinski načelnik izrađuju državni službenici. Obavljanje gotovo svih upravnih radnji (neke upravne radnje mogu obavljati i namještenici), vođenje upravnih postupaka bilo po službenoj dužnosti bilo po zahtjevu stranaka je u opisu poslova državnih službenika. Kako je jedinica lokalne samouprave mjesto gdje građani ostvaruju najveći broj svakodnevnih socijalnih, 
kulturnih, ekonomskih, riječju životnih potreba, a da u realizaciji bilo kojeg zahtjeva građanina je uključen državni službenik, očita je potreba da državni službenici budu moralni, profesionalni i pametni.

\section{KRIZA SLUŽBENIČKOG PRAVA U FEDERACIJI BOSNE I HERCEGOVINE}

Službeničko pravo u Federaciji BiH regulirano je zakonima donesenim na nivou Federacije BiH i na nivou federalnih jedinica. Do 2010. godine na području cijele Federacije BiH službeničko pravo regulirao je Zakon o državnoj službi u Federaciji Bosne i Hercegovine (u daljem tekstu ZDS). Međutim, Predsjednica Federacije $\mathrm{BiH}$ podnijela je Ustavnom sudu Federacije BiH zahtjev za ocjenu ustavnosti člana 1. ZDS u dijelu koji se odnosi na kantone, gradove i općine. Nakon razmatranja podnesenog zahtjeva, Ustavni sud Federacije BiH je donio presudu, broj U-27/09 od 20. IV. 2010. godine, u kojoj je utvrdio da odredba članka 1. u dijelu koji glasi „kantona, grada i općine“ nije u suglasnosti sa Ustavom Federacije BiH. Ustavni sud Federacije $\mathrm{BiH}$ je, pored ostalog, pošao od odredbi članka III stav 2. Ustava Federacije BiH kojim su utvrđene zajedničke nadležnosti Federacije BiH i kantona/ županija. Kao zajednička nadležnost, pored ostalih, utvrđena je socijalna politika koja obuhvata i oblast koja je regulirana ZDS. Kako je u ovom slučaju Parlament Federacije $\mathrm{BiH}$, bez suglasnosti kantona/županija, donio zakon kojim je regulirao oblast iz zajedničke nadležnosti, Ustavni sud je odlučio da je takav zakon neustavan.

Nakon navedene presude Ustavnog suda Federacije BiH, oblast službeničkog prava je na nivou federalnih jedinica bila podregulirana. Jedini propis koji se donekle mogao primijeniti na radno-pravni status državnih službenika u kantonima, gradovima i općinama bio je opći propis Zakon o radu Federacije Bosne i Hercegovine. Kantoni/županije su potom pokrenuli postupke reguliranja ove oblasti na nivou kantona. Danas, nekoliko kantona/županija imaju vlastite zakone o državnim službenicima, dok su neki od njih dali suglasnost i prihvatili federalni ZDS.

Krajem 2015. godine u okviru Reformske agende ${ }^{1}$ usvojen je Zakon o izmjenama i dopunama Zakona o državnoj službi u Federaciji Bosne i Hercegovine (u daljem tekstu: Zakon o izmjenama ZDS). Usvajanje Zakona o izmjenama ZDS je izazvalo brojne rasprave koje su se uglavnom fokusirale na član 11a. Zakona.

U suštini odredbama ovog člana utvrđeno je da sve rukovodeće pozicije imenuju politički organi vlasti, odnosno nositelji izvršnih funkcija organa vlasti. Iako je

1 Reformska agenda za Bosnu i Hercegovinu za period 2015-2018. godina, posvećuje jedno poglavlje reformi javne uprave ističući njen značaj za osiguranje fiskalne održivosti i kvalitetno pružanje usluga građanima. Agenda utvrđuje i obavezu Vijeća ministara BiH, entitetskih vlada, vlada kantona i Brčko distrikta da usvoje principe na kojima će se temeljiti reforma javne uprave. Također, utvrđuje se obveza donošenja novih zakona na svim razinama vlasti o državnim službenicima i uposlenicima za što bi pomoć trebali da pruže Svjetska banka i SIGMA, a sve to s ciljem olakšanja reforme javne uprave i uvođenja veće fleksibilnosti radnih aranžmana. 
Mr. sc. Jasmin Hušić: Uloga i značaj državnih službenika u ostvarivanju prava građana na lokalnu... Zbornik radova Pravnog fakulteta u Splitu, god. 54, 4/2017., str. 921.- 937.

članom 11b. Zakona o izmjenama ZDS predviđeno da se upošljavanje na pozicije iz člana 11a, isključujući savjetnike, vrši putem javnog konkursa, očita je politizacija ovih radnih mjesta, kako u procesu odabira kandidata tako i u obavljanju poslova tih radnih mjesta. Politizacija se ogleda u snažnom utjecaju osoba koje vrše imenovanje u postupku imenovanja i naravno davanja naloga i uputa za rad. Da su sve to političke pozicije, definitivno je potvrđeno članom 20. Zakona o izmjenama ZDS (član 6. Zakona o izmjenama ZDS), kojim se propisuje da se svim tim osobama iz člana 11a. ne jamči sigurnost uživanja položaja, te da mogu biti razriješeni dužnosti u bilo koje vrijeme. Istim članom je mandat osoba iz člana 11a. ograničen mandatom onih koji su ih imenovali. Članom 75b. regulirano je da će službenici koji budu zatečeni u državnoj službi na mjestima rukovodećih državnih službenika nakon stupanja na snagu ovoga zakona biti raspoređeni na odgovarajuća radna mjesta u okviru tijela državne službe.

Potpredsjednik Federacije BiH je podnio zahtjev Ustavnom sudu Federacije BiH za ocjenu ustavnosti određenih odredaba Zakona o izmjenama ZDS, ${ }^{2}$ kao i zahtjev za donošenje privremene mjere kojom bi se obustavila primjena odredbi člana 11a i $75 b$.

Ustavni sud Federacije BiH je postupajući po zahtjevu za donošenje privremene mjere utvrdio da je zahtjev osnovan i donio privremenu mjeru, broj U-13/16 od 28. VI. 2016. godine kojom je obustavio primjenu članova 11a. i 75b. Zakona o izmjenama ZDS. Nakon toga, Ustavni sud je donio i odluku kojom je utvrdio da Zakon o izmjenama ZDS nije u suglasnosti sa Ustavom Federacije BiH.

Ustavni sud Federacije BiH je utvrdio osnovanim navode i argumente podnosioca zahtjeva za ocjenu ustavnosti kojima je ukazano na povredu Međunarodnog pakta o građanskim i političkim pravima i Međunarodnog pakta o ekonomskim socijalnim i kulturnim pravima. Navedeni akti, u skladu sa odredbama Ustava BiH i Ustava Federacije $\mathrm{BiH}$ predstavljaju sastavni dio ustavnopravnog poretka Federacije $\mathrm{BiH}$. Sud je, obrazlažući svoj stav, pored ostalog, istaknuo da način na koji bi se popunjavala sva ta rukovodeća mjesta čini ih nedostupnim svim građanima koji za to imaju potrebne kvalifikacije. Taj slobodan pristup javnim službama garantiraju odredbe navedenih međunarodnih akata.

Na kraju, Ustavni sud Federacije je istaknuo: „,... sve osporene odredbe, u funkcionalnom sadejstvu, čine zakonodavni model koji bi postojeći koncept organizacije državne uprave bitno promijenio i to na način koji bi mogao ugroziti principe zakonitosti, transparentnosti i javnosti, odgovornosti prema građanima, efikasnosti i ekonomičnosti, te profesionalnosti i nepristrasnosti, a što su općeprihvaćeni principi na kojima treba počivati državna služba. Radna mjesta dosadašnjih rukovodećih državnih službenika, koji bi trebalo da čine okosnicu profesionalne, stabilne, kompetentne i neutralne državne službe, mogla bi se

2 Zahtjev za utvrđivanje ustavnosti odnosi se na član 5. st. 1, 2. i 3., članove 11a., 11.b, 75.a., 75.b. i 75.c. Zatim član 19. stav 1. tač. c), d) i f), član 20. i 25. stav 3, član 31. stav 1, član 33. stav 8, član 34. stav 2, član 35. stav 1, član 47. riječi ,i lica iz člana 11a. ovog zakona”, član 48., član 52. st. 1. i 2., te član 64. stav 3. Zakona o državnoj službi u Federaciji Bosne i Hercegovine. 
pretvoriti u radna mjesta za politički imenovane i mandatom ograničene zaposlenike na rukovodećim pozicijama u državnoj službi Federacije Bosne i Hercegovine, sa konačnim efektom kadrovske ekspanzije državnog aparata i izglednim pratećim budžetskim opterećenjima."

Ova materija bi se vjerovatno na sličan način regulirala i na kantonalnoj razini vlasti što podrazumijeva i općine. Međutim, kako je Ustavni sud donio privremenu mjeru i konačno utvrdio da je Zakon izmjenama ZDS neustavan, to se nije desilo.

Tako je Unsko-sanski kanton već utvrdio nacrt Zakona o državnoj službi Unskosanskog kantona u kojem je predviđeno da su rukovodioci državne službe (općinski načelnici/gradonačelnici na općinskom/gradskom nivou i ministri na kantonalnom nivou), nakon što se donese Zakon o državnoj službi, dužni donijeti Pravilnike o unutrašnjoj organizaciji i da izvrše rapored zatečenih uposlenika na mjesta za koja ispunjavaju uvjete. Prema tome, primjera radi, pomoćnik općinskog načelnika odnosno šef službe može biti raspoređen i na bilo koje niže radno mjesto kao što je stručni savjetnik, viši stručni saradnik ili stručni saradnik. S druge strane, uposlenika koji je na niže rangiranom radnom mjestu može rasporediti na mjesto pomoćnika načelnika. Sve to bez bilo kakvih kriterija kao što su: sposobnost, ocjena rada, napredovanje u službi i dr. Unsko-sanski kanton to čini već više puta i na taj način omogućuje pomjeranje uposlenika bez disciplinske odgovornosti i bez iskazanih vrijednosti pojedinih uposlenika i naravno bez konkursne procedure.

\section{4. ,DOBAR SLUŽBENIK“ VERSUS ,DOBRO UPRAVLJANJE“}

Dobar službenik podrazumijeva prisutnost te adekvatnu i sinhroniziranu aktivnost najvećih ljudskih i profesionalnih vrijednosti; od moralnih i karakternih, preko intelektualnih i stručnih do voljnih i emocionalnih. Dobar službenik je odraz tako usklađenog kompleksa vrijednosti u akciji.

Najčešće se profesionalizacijom državne uprave nastoji postići efekat dobrog upravljanja (good governance). Brojni su pokušaji uspostavljanja profesionalizma u državnoj službi, naročito kroz upravne reforme (administrative reforms) koje su sastavni dio procesa integracija $\mathrm{BiH}$ u EU. Međutim $\mathrm{BiH}$, utegnuta nesretnom i zlokobnom prošlošću koju po potrebi zazivaju istaknuti pojedinci, još uvijek hramajući sporo se kreće ka „good governance“. Svaki korak praćen je bar jednim kamenom spoticanja. Proces stabilizacije i pridruživanja (Stabilisation and Association process - SAP) započeli smo još davne 1999. godine. Tek 1. VI. 2015. godine stupio je na snagu Sporazum o stabilizaciji i pridruživanju (Stabilisation and Association Agreement) koji je potpisan još 16. VI. 2008. godine. Prema Izvještaju Europske komisje o napretku $\mathrm{BiH}$ za 2015. godinu, vrlo sporo napredujemo u postizanju onih vrijednosti EU koji bi se mogli sažeti u jednu sintagmu: dobro upravljanje (good governance).

Dakle, Europska unija, kroz pristupne kriterije nameće određenu obvezu primjene upravnih načela i standarda koje su dostigle i prihvatile članice EU. 
SIGMA $^{3}$ je kroz koncept europskog upravnog prostora definirala glavne europske upravne standarde. Europski upravni prostor kao normativni koncept kojeg je razvila SIGMA, predstavlja upravne institute, pravila, postupke i praksu koja je u primjeni u zemljama članicama EU; ,,svojevrsni idealtip suvremene europske javne uprave“" (Musa, 2010.).

Kao glavne principe upravnog prava koji su zajednički zemljama zapadne Europe SIGMA je izdvojila: 1. pouzdanost i predvidivost (pravna sigurnost), 2. otvorenost i transparentnost, 3. odgovornost i 4. efikasnost i djelotvornost (SIGMA, 1999.).

Pored principa upravnog prava SIGMA ističe uvjete koje državna služba (civil service) mora ispunjavati kako bi se postiglo efikasno i profesionalno djelovanje javne uprave. Naime, moderna, ustavna državna služba je moguća ako su ispunjeni slijedeći uvjeti (SIGMA, 1999.):

- razdvojenost javne od privatne sfere

- razdvojenost politike od uprave

- razvijenost pojedinačne odgovornosti državnih službenika

- jasno utvrđena prava i obaveze državnih službenika, te dovoljna sigurnost u pogledu zaposlenja i visine zarade

- zapošljavanje i napredovanje prema zaslugama.

Gotovo identičan koncept profesionalne državne službe SIGMA je istakla i 2014. godine utvrđujući principe javne uprave (SIGMA, 2014.). Pored principa razrađeni su i kvalitativni i kvantitativni indikatori za mjerenje ispunjenosti utvrđenih principa. Jedan od segmenata Principa javne uprave koje je utvrdila SIGMA nosi naziv Državna služba i upravljanje ljudskim potencijalima. ${ }^{4}$

U ovom dijelu Principa javne uprave postavljena su dva ključna zahtjeva i sedam principa.

Prvi ključni zahtjev podrazumijeva da je djelokrug državne službe jasno definiran i da se primjenjuje u praksi tako da postoji politika, pravni okvir i institucionalno uređenje za profesionalnu državnu službu.

Drugi postavljeni ključni zahtjev traži da se profesionalnost državne službe osigurava dobrim standardima u upravljanju i praksama upravljanja ljudskim potencijalima. Navedeni zahtjevi postižu se provedbom sedam principa:

Djelokrug državne službe je adekvatan, jasno definiran i primjenjuje se u praksi;

Uspostavljen je okvir politika i pravni okvir za profesionalnu i koherentnu državnu službu i primjenjuje se u praksi - institucionalno ustrojstvo omogućava

3 Support for Improvement in Governanace and Management in Central and Eastern European Countries predstavlja zajedničku inicijativu (program) Organizacije za ekonomsku saradnju i razvoj (OECD) i EU. Postoji od 1992. godine čiji je prvobitni cilj bio podrška pet zemalja srednje i istočne Europe u reformi državne uprave. Kasnije je SIGMA svoje djelovanje proširila i na druge zemlje.

4 SIGMA je principe javne uprave podijelila u nekoliko segmenata unutar kojih razrađuje ključne zahtjeve i principe (SIGMA, 2014.). Pored navedenog segmenta Državna služba i upravljanje ljudskim potencijalima, to su još: Strateški okvir reforme javne uprave; Izrada i koordinacija politika; Odgovornost; Pružanje usluga; Upravljanje javnim finansijama. 
Mr. sc. Jasmin Hušić: Uloga i značaj državnih službenika u ostvarivanju prava građana na lokalnu... Zbornik radova Pravnog fakulteta u Splitu, god. 54, 4/2017., str. 921.- 937.

konzistentne i djelotvorne prakse upravljanja ljudskim potencijalima širom državne službe;

Zapošljavanje državnih službenika zasnovano je na principu meritornosti i jednakom tretmanu u svim fazama zapošljavanja - kriteriji za raspored na niže rangirano radno mjesto i prekid radnog odnosa za državne službenike su eksplicitno postavljeni;

Spriječen je direktni ili indirektni politički utjecaj na rukovodeće pozicije u državnoj službi;

Platni sistem za državne službenike zasniva se na sistematizaciji radnih mjesta, pravičan je i tranparentan;

Osigurano je stručno usavršavanje državnih službenika, ono obuhvata redovno obučavanje, pravičnu ocjenu rada, mobilnost i unaprjeđenje, na temelju objektivnih i transparentnih kriterija i zasluga;

Postoje mjere za promoviranje integriteta i sprečavanje korupcije te za osiguravanje discipline u državnoj službi.

U Izvještaju o početnom mjerenju - principi javne uprave BiH (SIGMA, 2015.) korištenjem odgovarajućih indikatora pokušalo se utvrditi trenutno stanje javne uprave po segmentima kako su i razrađeni u Principima javne uprave.

Prvi princip je prema navedenom Izvještaju djelimično ispunjen. U Izvještaju se navodi: „Fragmentacija sistema državne službe predstavlja izazov jedinstvu pružanja usluga. Horizontalni djelokrug državne službe u BiH je adekvatan. Vertikalni djelokrug, naročito u državnim institucijama, daje razloge za brigu, pošto iz državne službe nisu isključene političke pozicije“" (SIGMA, 2015., str. 49.).

Drugi princip je također djelimično postignut. U Izvještaju je zaključeno: „Centralne jedinice za državnu službu zajedno su radile na uspostavljanju zajedničkog okvira za razvoj HRM, ${ }^{5}$ ali taj dokument nisu usvojili Vijeće ministara $\mathrm{BiH}$, Vlada FBiH ni Vlada RS. Ovo otežava opsežnu i garantiranu provedbu zajedničkih principa HRM u državnoj službi ravnomjerno u javnoj upravi u čitavoj BiH“. (SIGMA, 2015., str. 51.).

Što se tiče trećeg principa, u Izvještaju se zaključuje: „Propusti u zakonodavstvu, najčešće u vezi s visokim stepenom slobode ostavljenom rukovodstvu u postupku izbora kandidata, rezultiraju potencijalom za zapošljavanje i raskidanje radnog odnosa u državnoj službi. Visok broj žalbi na odluke o zapošljavanju može biti indikator ovog problema“" (SIGMA, 2015., str. 57.).

Četvrti princip da je spriječen direktni ili indirektni politički utjecaj na više rukovodeće političke pozicije u državnoj službi prema Izvještaju nije ispunjen.

Što se tiče ispunjenosti petog principa, u izvještaju se zaključuje: „Platni sistem zasniva se na sistematizaciji radnih mjesta. Međutim, koherentnost i pravičnost u čitavom sistemu državne službe nisu osigurani zbog različitih propisa na nivou države, entiteta i Brčko distrikta. Nedavno doneseno zakonodavstvo uvelo je

\footnotetext{
5 Skraćenica korištena u Izvještaju, HRM - upravljanje ljudksim potencijalima.
} 
transparentnost, ali je po provođenju analize poslova, potrebno uvesti veći stepen pravičnosti“ (SIGMA, 2015., str. 58.).

O ispunjenosti šestog principa u izvještaju se zaključuje: „Pravo i obveza stručnog usavršavanja navedeni su u zakonodavstvu, ali su sredstva za usavršavanje i obuke ograničena, a u slučaju Brčko distrikta budžet za obuku je sveden na nulu. Propisi o ocjenjivanju rada postoje, ali „napuhivanje“ ocjena pokazuje da se ovaj postupak provodi samo na papiru“" (SIGMA, 2015., str. 59.).

Što se tiče sedmog principa, u Izvještaju je zaključeno da je Agencija za prevenciju korupcije i koordinaciju borbe protiv korupcije u 2014. godini bila aktivna samo na državnom nivou, gdje su planovi za borbu protiv korupcije doneseni od pojedinih organa uprave, ali Agencija ima ograničena ovlaštenja za provedbu ovih planova (SIGMA, 2015., str. 60.).

Dakle, ,stvaranje“ dobrog službenika je trajan, veoma kompleksan i nimalo lak proces koji podrazumijeva multivrijednosni pristup u kojem dominira moralno i stručno. Nije to proces koji se može odvijati po unaprijed zadanoj formuli, proces za koji postoji recept. I to je uvijek slučaj kada je objekt čovjek. Čovjek je prosto toliko individualiziran svojom prošlošću (nasljeđem, rođenjem, odrastanjem), svojim intelektualnim (inteligencija, obrazovanje, usavršavanje), socijalnim (načinom života i rada, okolinom, navikama, stavovima) i emocionalnim habitusom, da ga se ne može „ugurati“ u bilo kakav unaprijed zadani model. Pristup „copy - paste“ je vrlo često korišten u reformskim procesima u oblasti uprave i lokalne samouprave. Međutim, takav pristup najčešće je popraćen neuspjehom ili nedovoljnim efektom. Smatramo da ne postoji precizan model upravljanja složenim sistemima kao što je državna uprava ili lokalna samouprava koji bi bio panaceja za sve upravne/ samoupravne sisteme. Svako ustrojstvo (upravnog) sistema mora uzeti u obzir sve elemente koji ga tvore postavljajući ih u konstelaciju koja će moći dati najkvalitetniji odgovor na zahtjeve bez obzira da li ti zahtjevi dolazili iznutra (producirani od strane sistema) ili spolja (producirani izvan struktura sistema). Takva tvorba omogućava uvažavanje i uključivanje svih bitnijih osobitosti i specifičnosti sistema i struktura sistema koje su rezultanta vanjskih i unutrašnjih procesa. S tim u vezi, mišljenja smo da kod ustrojavanja upravnih i samoupravnih sistema treba dozvoliti autopoietski pristup u smislu davanja prednosti samotvorbi i samoorganizaciji. Naravno, i takav pristup, da bi uspješno obavio zadaću, mora podrazumijevati ispravan sistem vrijednosti. Tako Lauc naglašava: „Najbolja su rješenja poštena i pametna, unutar kojih se prepoznaje važnost: (1) moralnog kapitala, (2) intelektualnog, (3) socijalnog kapitala, (4) fizičkog kapitala i (5) financijskog kapitala“ (Lauc Z., 2010.). 


\section{NEMA DOBRE UPRAVE BEZ MORALNOG I PAMETNOG DRŽAVNOG SLUŽBENIKA}

Najneposredniji doživljaj vlasti građanin ima na lokalnoj razini, u jedinicama lokalne samouprave (općinama i gradovima) gdje se, kako je to utvrđeno Ustavom Federacije BiH i Zakonom o principima, ostvaruje lokalna samouprava. Kakav će doživljaj građanin imati, svakako ovisi od toga kakva je uprava; da li je „dobra“ ili „loša“, u čemu presudnu ulogu imaju državni službenici.

Svaka društvena aktivnost mora biti zasnovana na „moralnom imperativu“. Princip moralnog potencira se i kroz principe javne uprave (SIGMA, 2014.). Naročito je to inherentno principima koji insistiraju na zapošljavanju državnih službenika koje je zasnovano na principu meritornosti i jednakom tretmanu u svim fazama zapošljavanja - kriteriji za raspored na niže rangirano radno mjesto i prekid radnog odnosa za državne službenike su eksplicitno postavljeni; zatim princip koji zahtijeva mjere za sprečavanje korupcije.

Jedna od najtežih bolesti državne službe, naročito u $\mathrm{BiH}$, jeste korupcija koja je mutirala u različite oblike i značajno zahvatila upravu. Prema istraživanju Trancparency International, BiH se nalazi na 83. mjestu od ukupno 176 zemalja u kojima je vršeno istraživanje sa ocjenom 39, na skali od 0 do 100, gdje 0 predstavlja najviši nivo percepirane korupcije, a 100 predstavlja najniži nivo. ${ }^{6}$ Imajući u vidu prirodu i obilježja kaznenog djela korupcije (biće kaznenog djela), u čijem počinjenju sudjeluju i službena osoba koja prima određen oblik koristi ili obećanje da će takvu korist ostvariti i osoba koja daje/nudi ili obećava, što povlači odgovornost obiju strana, jasno je da najčešće takva djela ostaju neotkrivena. Obje strane (oba počinitelja) imaju interes da djelo ostane neotkriveno. Pored toga, djelo korupcije najčešće se čini (traži/zahtijeva ili daje/nudi) prešutno i bez uočljivih tragova. Sve to čini da je tamna brojka ovog kaznenog djela dosta veća u odnosu na mnoga druga kaznena djela. U takvim okolnostima organi gonjenja ne dolaze do izražaja kada je riječ o ekspeditivnosti i efektivnosti. Sve to ukazuje da je moralni imperativ u djelovanju, naročito kod službene osobe, ključan. Stoga, moralnost jeste kapital koji mora zauzimati prvo mjesto i biti imperativ našeg djelovanja jer na njemu (moralnom kapitalu) počivaju sve druge vrijednosti.

Značaj stručnosti i svakodnevnog obrazovanja državnih službenika istaknut kroz principe javne uprave koje je formulisala SIGMA (2014.), najjasnije se izražava u principima koji zahtijevaju zapošljavanje državnih službenika na principu meritornosti te da se osigura stručno usavršavanje državnih službenika, koje obuhvata redovno obučavanje, pravičnu ocjenu rada, mobilnost i unapređenje, na temelju objektivnih i transparentnih kriterija i zasluga.

6 BiH poziciju na listi CPI dijeli sa Albanijom, a i dalje se nalazi ispod Hrvatske (ocjena 49 i 55. mjesto), Crne Gore (ocjena 45 i 64. mjesto) i Srbije (ocjena 42 i 72. mjesto), dok su ispod BiH Makedonija, koja je najviše nazadovala u regionu (nalazi se na 90. mjestu, sa ocjenom 37) i Kosovo (ocjena 36 i 95. mjesto). 
Naglašena uloga znanja u razvoju i napretku potencirana je i u strategiji za pametan, održiv i inkluzivan rast, Europa 2020, koju je EU, kako bi pomogla zemljama članicama da lakše prebrode ekonomsku krizu, usvojila 2010. godine.

Znanje je osnova za bilo kakvu aktivnost. Uloga i značaj znanja je naročito potencirana kroz teorije intelektualnog kapitala. Tu treba istaći Roberta Solowa, poznatog ekonomskog teoretičara iz pedesetih godina prošlog stoljeća i jednog od najistaknutijih analitičara Teorije rasta. Zatim, Paul Romer, koji je krajem prošlog stoljeća razvio Endogenu teoriju rasta ističući ključnu ulogu znanja i ideja u ekonomskom rastu (Kolaković, M., 2003.).

Pravo i obaveza stručnog usavršavanja državnih službenika utvrđena je i zakonima o državnoj službi (federalnim i kantonalnim). Međutim, najčešće se u praksi dodatno usavršavanje svodi na povremene seminare kojima prisustvuje veoma mali broj državnih službenika. Značajnu ulogu u organiziranju seminara i tečajeva ima Agencija za državnu službu Federacije BiH.

Smisao lokalne samouprave mogli bismo definirati potrebom i pravom građanina da neposredno (koliko je to moguće) kreira svoj životni ambijent u kojem će moći svoje osnovne ekonomske, socijalne, kulturne, sigurnosne, komunalne i dr. životne potrebe ostvarivati kvalitetno, efikasno i potpuno na način koji će osiguravati njegov moralni i fizički integritet i dostojanstvo. Za takvu lokalnu samoupravu nužna je „dobra uprava“ za čije postizanje je conditio sine qua non „dobar državni službenik“.

ZDS (član 4.), isto tako i kantonalni zakoni o državnoj službi utvrđuju principe čije poštivanje i primjenu treba da osigura državna služba (državni službenici). To su: zakonitost, transparentnost i javnost, odgovornost, efikasnost i ekonomičnost, profesionalna nepristrasnost i na kraju politička nezavisnost. Dakle, skup načela koji definiraju dobrog državnog službenika koji je moralan i stručan.

Takav državni službenik koji je moralan, stručan i politički neovisan ne samo da će na najbolji mogući način svoje aktivnosti usmjeriti na realizaciju građanskih legalnih potreba i interesa, što jeste ostvarivanje lokalne samouprave, već će hrabro i dostojanstveno, svojim vrijednostima braniti bastion demokratije.

U Bosni i Hercegovini, naročito na višim razinama vlasti, demokratija je u ozbiljnoj krizi. Konstantno forsiranje nacionalnih, političkih, vjerskih, ekonomskih i drugih interesa u ime građana rezultira usporavanjem ili potpunim zaustavljanjem napretka na putu ka EU i NATO integracijama, rezultira jačanjem osjećaja nesigurnosti i prijetnji, rezultira sistemskim iscrpljivanjem ekonomske moći građana i drugim negativnostima čiji teret in fine nose upravo građani.

Na nižim razinama vlasti suprotstavljenost interesa je manje prisutna što može predstavljati priliku za izgradnju životnog ambijenta u kojem će građanin biti zadovoljan. To je suština lokalne samouprave - zadovoljan građanin. Međutim, sve dok profesionalan i politički neovisan državni službenik (naročito rukovodeći državni službenik), bude doživljavan od strane političkih struktura vlasti kao balast i prijetnja i sve dok moral državnih službenika ne bude jači od straha za vlastite ekonomske interese i dok moral državnih službenika ne bude jači od konstantno 
pulsirajućih izazova i želje za lakim i brzim finansijskim dobitkom, nema dobrog državnog službenika, nema dobre uprave i zadovoljnog građanina.

Kako se oduprijeti svim tim pritiscima i izazovima? Na jednoj strani politički interesi koji teže neutralizaciji profesionalnog i neovisnog i na drugoj stani unutrašnja borba sa lakomim sobom koji hoće više, brzo i odmah. Odgovor je u moralnom i pametnom državnom službeniku. Službeniku koji će, bez obzira na cijenu, ostati kod moralnih načela i zakonitosti i koji neće posustati pod pritiscima nezakonitog i nemoralnog. Pored toga državni službenik mora kontinuirano raditi na vlastitom obrazovanju i usavršavanju. Stručan državni službenik je, s jedne strane, garancija vlastitoj sigurnosti jer kao takav ima kapacitet da se odupre pritiscima, prijetnjama i drugim oblicima ugrožavanja od strane kvazibrižnika građanskog dobra, a s druge strane garancija efikasnog i kvalitetnog rješavanja zahtjeva građana. Dakle, državni službenik mora htjeti (moralan) i mora znati (pametan/stručan) pružiti takav otpor. Tek takav može biti garant lakšeg ostvarivanja prava građana na lokalnu samoupravu.

U tom smislu, nove izmjene i dopune ZDS koje su ponovo u pripremi, nakon što je Ustavni sud Federacije BiH donio odluku da je Zakon o izmjenama ZDS neustavan, mora uzeti u obzir temeljna načela službeničkog prava koja predstavljaju standard u EU.

Takvi se standardi moraju uspostaviti na federalnoj razini kako bi poslužili kao model kantonalnim vlastima kod reguliranja oblasti službeničkog prava.

Mogućnost, koja je utvrđena Ustavom Federacije BiH kao zajednička nadležnost federalne i kantonalne vlasti, da kantonalne vlasti uređuju pitanja radno-pravnog statusa državnih službenika na svom području, rezultirala je različitim rješenjima u ovoj oblasti, od kantona do kantona. Tako u jednom kantonu (Unsko-sanski kanton) je mjesto inspektora (iako su državni službenici) ograničeno na mandatni period od tri godine, u drugim kantonima to nije slučaj. Postavlja se pitanje koliko će inspektor biti spreman izricati sankcije i nalagati mjere kao što je mjera uklanjanje građevinskog objekta, ako zna da za kratko vrijeme neće biti inspektor. Pojedini kantoni su donijeli zakone o državnoj službi, dok su drugi prihvatili Zakon o državnoj službi Federacije BiH. Razlike postoje i kod postupka zapošljavanja, definiranja rukovodećeg državnog službenika, disciplinskog postupka, nadležnosti Agencije za državnu službu u Federaciji BiH i dr.

Zakonska rješenja pojedinih kantona u manjoj ili većoj mjeri omogućavaju „prejak“ utjecaj izvršnih organa vlasti na izbor/postavljenje ili otpuštanje državnog službenika. Primjera radi u Nacrtu zakona o državnoj službi u Unskosanskom kantonu u članu 49. propisano je da rukovodilac organa državne službe može rasporediti na neposredno niže upražnjeno radno mjesto ukoliko „uoči da ne vrši pravilno i na zakonu predviđen način poslove iz svoje nadležnosti i da su zbog neefikasnog, neekonomičnog ili neodgovornog rukovođenja osnovnom organizacionom jednicom nastale ili mogu nastati štetne posljedice po prava i dužnosti građana, pravnih lica i drugih subjekata ili posljedice po javni interes.“ Naravno ukoliko neposredno niže radno mjesto nije sistematizovano ili nije 
upražnjeno tada se rukovodeći službenik može rasporediti na slijedeće niže radno mjesto. U ovom slučaju, kako je to predviđeno u Nacrtu zakona, žalba ne odlaže izvršenje. Dakle, dovoljno je da rukovodilac „uoči“ određene nepravilnosti koje imaju negativne posljedice ili bi mogle imati, pa da rukovodeći državni službenik bude smijenjen, tj. raspoređen na neko niže radno mjesto. Nema dokazivanja, nema disciplinskog postupka i nema suspenzivnog dejstva žalbe. Dovoljno je obrazložiti. Time će, ukoliko se usvoji takvo rješenje, rukovodeći državni službenici biti dovedeni u nestabilan položaj u kojem, nezaštićeni, neće moći pružiti potreban otpor nezakonitim zahtjevima političkih struktura predstavljenih u rokovodiocima organa (općinski načelnik, ministar, premijer, direktor i sl.).

Tako uređen sistem državne službe, razjedinjen i osjetljiv na političke utjecaje, ne može biti odgovor na zahtjeve koje postavljaju EU standardi, a koji insistiraju na profesionalizmu, stručnosti i političkoj neovisnosti državnih službenika. Stoga, novim zakonom o državnoj službi u Federaciji $\mathrm{BiH}$, koji je trenutno u fazi pripreme nacrta, da bi se zadovoljio minimum EU standarda, moraju biti utvrđeni principi na kojima će se zasnivati i kantonalni propisi iz oblasti službeničkog prava. Tu svakako mora doći do izražaja stručnost i neovisnost državnih službenika, naročito rukovodećih.

\section{ZAKLJUČAK}

Lokalna samouprava ostvaruje se u jedinicama lokalne samouprave tj. u općinama i gradovima. Prema Europskoj povelji o lokalnoj samoupravi i prema Zakonu o principima, lokalna samouprava jeste ,pravo i osposobljenost jedinica lokalne samouprave da, u granicama zakona, reguliraju i upravljaju određenim javnim poslovima na osnovu vlastite odgovornosti i u interesu lokalnog stanovništva“. Pored organa jedinica lokalne samouprave, ključnu ulogu u ostvarivanju lokalne samouprave imaju državni službenici koji predstavljaju servis građana u postupcima ostvarivanja prava. Pravo građana na dobru upravu regulira, pored ostalog, i Povelja o temeljnim pravima Europske unije (član 41.). To pravo regulirano je i Zakonom o upravnom postupku Federacije Bosne i Hercegovine; načelo zaštite prava građana i zaštite javnog interesa (član 5.), načelo efikasnosti (član 6.), načelo saslušanja stranke (član 8.) i niz drugih odredaba koji garantiraju pravo pristupa i sudjelovanja u postupcima, pravo žalbe, pravo na pomoć, zabranu diskriminacije i dr. Međutim, državni službenici koji rade na rješavanju zahtjeva stranaka neposredno su uključeni u postupke kroz koje građani ostvaruju pravo na dobru upravu odnosno na lokalnu samoupravu. Od njih (službenika) ovisi, u značajnoj mjeri, da li će građani taj put proći na lakši (dobra uprava) ili teži način (loša uprava). Slijedi da je dobra uprava i ostvarivanje prava na lokalnu samoupravu uvjetovano dobrim državnim službenikom koji je moralan i pametan. Takav državni službenik i takva uprava kojima su svojstvena načela europskog upravnog prostora i europskog upravljanja (dobrog upravljanja) te načela koja, s tim u vezi, razvija SIGMA, treba da je imperativ uprave i upravnog djelovanja. Samo na takav način i uz negaciju negacije 
specifičnosti i osobitosti sistema i okoline, uvažavajući načelo samoorganizacije i poredak vrijednosti: moralno, intelektualno, socijalno, fizičko i financijsko, možemo dosegnuti dobru upravu i lokalnu samoupravu.

\section{LITERATURA}

Europe 2020, „A strategy for smart, sustainable and inclusive growth“, Brussels, COM (2010.) dostupno na: http://eur-lex.europa.eu/LexUriServ/LexUriServ. do?uri=COM:2010:2020: FIN:EN:PDF.

Kolaković, M., 2003., „Teorija intelektualnog kapitala“, Ekonomski pregled, 54 (11-12) 925-944.

Lauc, Z., 2010., „Odnos države i samouprave promatran kroz načelo supsidijarnosti“, Anali Zavoda za znanstveni i umjetnički rad u Osijeku, sv. 26, str. 23-36.

Musa, A., 2010., „Pojmovnik“, Hrvatska javna uprava, br. 1, str. 297-308.

„Reformska agenda za Bosnu i Hercegovinu za period 2015-2018. godine“, dostupno na: http://www.fbihvlada.gov.ba/pdf/Reformska\%20agenda.pdf, pristupljeno 22. VII. 2016. godine.

SIGMA, 1999., „Europski principi za državnu upravu“, dokument br. 27, OECD, Paris, dostupno na: http://sigmaweb.org/publications.

SIGMA, 2014., „The Principles of Public Administration“, OECD, Paris, dostupno na: http://www.sigmaweb.org/publications/Principles-Public-Administration-Nov2014.pdf.

SIGMA, 2015., „Baseline Measurement Report: The Principles of Public Administration Bosnia and Herzegovina“, OECD, Paris, dostupno na: http://www.sigmaweb.org/ publications/public-governance-baseline-measurement-reports.htm.

Šmidovnik, J., 1999., Lokalna samouprava, Studentska štamparija Univerziteta u Sarajevu, Sarajevo.

\section{Propisi}

Ustav Federacije Bosne i Hercegovine, Službene novine Federacije Bosne i Hercegovine, br. 1/94, 13/97, 16/02, 22/02, 52/02, 63/03, 9/04, 20/04, 33/04, 71/05, 72/05, 88/08.

Zakon o principima lokalne samouprave u Federaciji Bosne i Hercegovine, Službene novine Federacije Bosne i Hercegovine, br. 49/06.

Zakon o upravnom postupku, Službene novine FBiH, br. 2/98 i 48/99.

Zakon o državnoj službi u Federaciji Bosne i Hercegovine, Službene novine Federacije Bosne i Hercegovine, br. 29/03, 23/04, 39/04, 54/04, 67/05, 8/06 i 4/12.

Zakon o izmjenama i dopunama Zakona o državnoj službi u Federaciji Bosne i Hercegovine (Službene novine Federacije Bosne i Hercegovine, broj: 99/15), 
Zakon o organizaciji organa uprave u Federaciji Bosne i Hercegovine, Službene novine Federacije Bosne i Hercegovine, br. 35/05.

Uredba o ratifikaciji Europske povelje o lokalnoj samoupravi, Službeni list RBiH, br. $31 / 94$.

\section{Presude}

Ustavni sud Federacije Bosne i Hercegovine, presuda broj U-13/16 od 7. XII. 2016. godine (,Službene novine Federacije Bosne i Hercegovine, broj 9/17).

Ustavni sud Federacije Bosne i Hercegovine, presuda broj U-27/09 od 20. IV. 2010. godine (,,Službene novine Federacije Bosne i Hercegovine, broj 34/10).

\section{THE ROLE AND IMPORTANCE OF CIVIL SERVANTS IN THE EXERCISE OF THE CITIZENS RIGHT TO LOCAL SELF- GOVERNMENT IN THE FEDERATION OF BOSNIA AND HERZEGOVINA}

A brief overview of the constitutional order of Bosnia and Herzegovina and the Federation of Bosnia and Herzegovina and the position of local self-government in the vertical structure of government is provided in the paper. In addition, the issue of the organization and jurisdiction of local self-government is treated. The issue of the right to local self-government guaranteed by the Constitution of the Federation of Bosnia and Herzegovina is addressed in this paper. The right of civil servants in the Federation of Bosnia and Herzegovina, the attitude of political structures to professional independence of civil servants and the role and importance that civil servants should have in the processes of exercising civil rights, and the right to local self-government is what the research is focused on. The necessity of harmonization of cantonal legislation on civil service law with federal legislation, and the need to base the civil service law on the principles and standards achieved in the EU is what the paper points out.

Keywords: local self-government, the Federation of Bosnia and Herzegovina, a civil servant, good governance 